\title{
A Cohort Analysis Of Black-White Income Differentials In The South, 1960-1970\#
}

\author{
Eui Hang Shin* \\ INTRODUCTION
}

A review of recent literature on racial differentiation in income reveals several recurring shortcomings. First, a complete description of the recent trends is not available on a cohort basis. Only through a cohort approach is it possible to trace the changing processes of black-white income inequality. Farley and Hermalin (1972:359) noted the discrepancies between the secular trends and cohort changes in black-white inequality in income. It is believed that an intracohort analysis will specify the changes over time within each cohort, whereas examination of the intercohort and cross-sectional variations may not.

Secondly, a black-white comparison of family income, which has been used in many previous studies, may not indicate the actual racial inequality in economic well-being, since the family income differentials are partially due to the race differences in the family structure and the labor force participation of wives (Bogue, 1969: 415-417; U.S. Bureau of the Census, 1971:1-2; Moynihan, 1972:10; U.S. Bureau of the Census, 1974: 1). Comparisons of personal income between black and white males more directly indicate the racial difference in the monetary renumerations for the labor market activities.

Thirdly, previous studies generally lack a detailed analysis of the interstate variations in the extent of black-white income gap within a specific region. As Cook (1970:147) pointed out, the historical uniqueness of the race relations in the South and the consistent findings of a greater race differential in income in the South than in nonsouthern regions in previous studies necessitate a further detailed analysis of the recent trends of race differentials in income within the South. Furthermore, considering the significant variations in the extent of black-white income differentials among states within the South, it is desirable to use a geographic unit smaller than the region.

The primary purpose of the present study is to analyze the patterns of intracohort changes in the black-white male income differentials in each of ten selected Southern states between 1960 and 1970. The analysis includes a set of comparisons of the trends and variations in black-white

\#Revised version of a paper presented at the 1974 Annual Meeting of the American Sociological

Association, Montreal, Canada, August 25-29, 1974.

*Department of Sociology, University of South Carolina. 
income differentials: among selected Southern states at specified points in time and over time; between Southern states and Northern states; between Southern states and the United States as a whole. The ten Southern states considered in this study are Virginia, North Carolina, South Carolina, Georgia, Florida, Tennessee, Alabama, Mississippi, Arkansas, and Louisiana. These ten Southern states were selected because of their common historical background; all were Secessionist states. However, one of the Secessionist states, Texas, is not included in this study, because the large proportion of Mexican-American population among the total white population of Texas unduly complicates any analyses of black-white differentials. Also, for a South-North comparison, seven Northern states are selected: New York, New Jersey, Pennsylvania, Ohio, Indiana, Illinois, and Michigan. These seven states are selected on the basis of their having a large concentration of the total black population in the North. As of the 1970 Census, these states had about 84 percent of the blacks in the Northeast and North Central (U.S. Bureau of the Census, 1972: Table 60).

\section{DATA AND METHOD}

The data used in this study are drawn mainly from the published reports of the 1960 and 1970 Census of Population. Although fairly detailed data on income cross-classified by various characteristics are available for each state, some limitations of the data must be noted. First, underenumeration in the censuses, particularly significant race differentials in the degree of underenumeration, can distort the measurement of black-white income differentiation from the census data. According to an evaluation of the 1970 Census-coverage (Siegel, 1974: 1-23) "net underenumeration rate" was about 1.9 percent for whites and 7.7 percent for blacks. The net underenumeration rates were 17 to 19 percent for black males at ages 25 to 44 . Thus, if the income characteristics of those who were not counted in the census were substantially different from the characteristics of those enumerated in the census, such enumeration errors would affect analysis of black-white differentials in income. (Given that blacks and low income groups are most likely to be missed in the census enumeration, the possible bias is an under-estimation of blackwhite income difference.)

Secondly, in the 1970 Census reports the tables on income by race used white-Negro categorization of race groups, whereas white-nonwhite categories were used for the corresponding tabulations in the 1960 census volumes. Thus, in a strict sense, these two sets of data are not comparable. Nevertheless, since the representation of nonwhites other than blacks in the total nonwhite population in each of the Southern and Northern states considered in this study is very small, such a change in categorization of race groups in the income data is not likely to influence our analysis. Although there are other types of limitations of the data, we have attempted to make the two sets of data, data for 1960 and 1970, 
as comparable as possible by collapsing categories and rearranging the format of data.

In this study, index of dissimilarity or delta (Duncan and Duncan, 1955; Siegel, 1965; Taeuber and Taeuber, 1965b; Farley and Hermalin, 1972 ) is used as a measure of black-white income differentials. This index indicates the percentage of blacks (or whites) who would have to be redistributed in order for the income distributions of blacks and whites to be the same. The index of dissimilarity ranges from 0 to 100 , and higher values indicate greater income differentials between the two race groups. The indices of dissimilarity between black and white male income distributions (based on 9 income categories) were calculated for each age group in both 1960 and 1970. For an examination of interstate variations in the extent of black-white income differentials, we compared the age-specific-indices of dissimilarity among the states in 1960 and 1970. In order to analyze the intracohort changes in the income differentials, the index of dissimilarity of a cohort observed in 1960 was compared with that of the same cohort in 1970: for example, the index for the 25-34 age group in 1960 versus the index for the 35-44 age group in 1970.

It should be pointed out that the intracohort changes obtained from such a comparison are the net results of several components (changes in an "open cohort" over time): changes in race differentials in income distributions due to race-income differentials in mortality, migration, and those which are not accounted for by mortality and migration factors. In a strict sense, only the intracohort changes in race differentials which are not influenced by race-income differentials in mortality and migration (changes in a "closed cohort" over time) would indicate whether or not the racial inequality in income has been reduced. Previous studies (Hamilton, 1964; Price, 1965; Shryock and Nam, 1965; Suval and Hamilton, 1965; Taeuber and Taeuber, 1965a; Cutright, 1974; Long and Heltman, 1974) found significant differentials and selectivities of migration to and from the South, particularly socioeconomic selectivities of black out-migration from the South. Thus, we should expect that migration factors will influence considerably our analysis of the intracohort changes in race differentials in income in the Southern states. Also, in-migration of Southern blacks must have influenced the intracohort changes in the race differentials in income in the Northern states. Since it is not possible, with the available data, to decompose the total intracohort changes into the different terms, our analysis here is limited to the general comparisons of the race differentials in income of the "open cohorts" between 1960 and 1970.

\section{ANALYSIS}

Before presenting the findings of the intracohort analysis, it is desirable to review the general features of black-white income differentials. In 1970, for the United States as a whole, the median incomes of persons 14 years old and over were $\$ 4,067$ for black males and $\$ 6,712$ for white 
TABLE 1. Indices of Dissimilarity between Income Distributions of Black and White Males, by Age and State, for Selected Southern States, 1960 and 1970.

\begin{tabular}{|c|c|c|c|c|c|c|c|c|c|}
\hline . & & Total, $20+$ & $20-24$ & $25-34$ & $35-44$ & $45-54$ & $55-64$ & $65-74$ & $75+$ \\
\hline United States: & $\begin{array}{l}1960 \\
1970\end{array}$ & $\begin{array}{l}32.9 \\
27.9\end{array}$ & $\begin{array}{r}22.6 \\
9.6\end{array}$ & $\begin{array}{l}38.6 \\
32.7\end{array}$ & $\begin{array}{l}40.5 \\
36.7\end{array}$ & $\begin{array}{l}39.3 \\
37.2\end{array}$ & $\begin{array}{l}35.1 \\
33.8\end{array}$ & $\begin{array}{l}27.0 \\
28.0\end{array}$ & $\begin{array}{l}26.4 \\
24.5\end{array}$ \\
\hline Virginia: & $\begin{array}{l}1960 \\
1970\end{array}$ & $\begin{array}{l}36.2 \\
33.6\end{array}$ & $\begin{array}{l}19.7 \\
10.4\end{array}$ & $\begin{array}{l}41.8 \\
38.3\end{array}$ & $\begin{array}{l}47.6 \\
46.6\end{array}$ & $\begin{array}{l}42.6 \\
45.1\end{array}$ & $\begin{array}{l}35.8 \\
36.9\end{array}$ & $\begin{array}{l}26.5 \\
28.1\end{array}$ & $\begin{array}{l}22.2 \\
22.8\end{array}$ \\
\hline North Carolina: & $\begin{array}{l}1960 \\
1970\end{array}$ & $\begin{array}{l}39.5 \\
34.0\end{array}$ & $\begin{array}{l}27.9 \\
14.7\end{array}$ & $\begin{array}{l}49.0 \\
38.8\end{array}$ & $\begin{array}{l}49.4 \\
44.8\end{array}$ & $\begin{array}{l}42.3 \\
42.2\end{array}$ & $\begin{array}{l}35.3 \\
35.6\end{array}$ & $\begin{array}{l}25.2 \\
21.3\end{array}$ & $\begin{array}{l}19.3 \\
19.1\end{array}$ \\
\hline South Carolina: & $\begin{array}{l}1960 \\
1970\end{array}$ & $\begin{array}{l}47.7 \\
41.1\end{array}$ & $\begin{array}{l}35.2 \\
16.4\end{array}$ & $\begin{array}{l}57.4 \\
47.4\end{array}$ & $\begin{array}{l}58.7 \\
53.6\end{array}$ & $\begin{array}{l}53.4 \\
51.9\end{array}$ & $\begin{array}{l}43.3 \\
43.0\end{array}$ & $\begin{array}{l}35.1 \\
26.6\end{array}$ & $\begin{array}{l}26.2 \\
29.2\end{array}$ \\
\hline Georgia: & $\begin{array}{l}1960 \\
1970\end{array}$ & $\begin{array}{l}43.2 \\
35.9\end{array}$ & $\begin{array}{l}28.3 \\
16.6\end{array}$ & $\begin{array}{l}51.8 \\
42.8\end{array}$ & $\begin{array}{l}51.6 \\
48.1\end{array}$ & $\begin{array}{l}46.2 \\
47.3\end{array}$ & $\begin{array}{l}38.6 \\
39.8\end{array}$ & $\begin{array}{l}30.8 \\
23.7\end{array}$ & $\begin{array}{l}24.3 \\
24.4\end{array}$ \\
\hline Florida: & $\begin{array}{l}1960 \\
1970\end{array}$ & $\begin{array}{l}40.3 \\
33.6\end{array}$ & $\begin{array}{l}23.5 \\
12.1\end{array}$ & $\begin{array}{l}52.0 \\
40.0\end{array}$ & $\begin{array}{l}56.6 \\
52.2\end{array}$ & $\begin{array}{l}49.9 \\
49.4\end{array}$ & $\begin{array}{l}39.4 \\
40.4\end{array}$ & $\begin{array}{l}34.4 \\
38.7\end{array}$ & $\begin{array}{l}39.4 \\
41.3\end{array}$ \\
\hline Tennessee: & $\begin{array}{l}1960 \\
1970\end{array}$ & $\begin{array}{l}30.5 \\
27.3\end{array}$ & $\begin{array}{l}22.2 \\
13.8\end{array}$ & $\begin{array}{l}39.3 \\
29.8\end{array}$ & $\begin{array}{l}39.3 \\
36.9\end{array}$ & $\begin{array}{l}32.0 \\
35.4\end{array}$ & $\begin{array}{l}28.4 \\
26.8\end{array}$ & $\begin{array}{l}18.6 \\
17.3\end{array}$ & $\begin{array}{l}18.9 \\
16.0\end{array}$ \\
\hline Alabama: & $\begin{array}{l}1960 \\
1970\end{array}$ & $\begin{array}{l}37.0 \\
35.1\end{array}$ & $\begin{array}{l}33.9 \\
23.9\end{array}$ & $\begin{array}{l}47.7 \\
42.9\end{array}$ & $\begin{array}{l}46.0 \\
44.8\end{array}$ & $\begin{array}{l}36.2 \\
39.4\end{array}$ & $\begin{array}{l}29.0 \\
32.2\end{array}$ & $\begin{array}{l}24.5 \\
22.4\end{array}$ & $\begin{array}{l}19.7 \\
16.9\end{array}$ \\
\hline Mississippi: & $\begin{array}{l}1960 \\
1970\end{array}$ & $\begin{array}{l}42.8 \\
40.7\end{array}$ & $\begin{array}{l}36.3 \\
21.9\end{array}$ & $\begin{array}{l}55.6 \\
49.1\end{array}$ & $\begin{array}{l}56.7 \\
52.9\end{array}$ & $\begin{array}{l}45.6 \\
49.4\end{array}$ & $\begin{array}{l}38.7 \\
39.6\end{array}$ & $\begin{array}{l}29.7 \\
27.5\end{array}$ & $\begin{array}{l}22.2 \\
23.7\end{array}$ \\
\hline Arkansas: & $\begin{array}{l}1960 \\
1970\end{array}$ & $\begin{array}{l}35.5 \\
32.3\end{array}$ & $\begin{array}{l}33.0 \\
21.3\end{array}$ & $\begin{array}{l}48.5 \\
39.2\end{array}$ & $\begin{array}{l}\mathbf{4} 7.7 \\
39.8\end{array}$ & $\begin{array}{l}38.7 \\
40.0\end{array}$ & $\begin{array}{l}31.0 \\
30.9\end{array}$ & $\begin{array}{l}23.8 \\
24.8\end{array}$ & $\begin{array}{l}18.7 \\
18.6\end{array}$ \\
\hline Louisiana: & $\begin{array}{l}1960 \\
1970\end{array}$ & $\begin{array}{l}44.3 \\
39.4\end{array}$ & $\begin{array}{l}32.3 \\
21.6\end{array}$ & $\begin{array}{l}52.7 \\
46.5\end{array}$ & $\begin{array}{l}53.5 \\
50.0\end{array}$ & $\begin{array}{l}45.5 \\
46.3\end{array}$ & $\begin{array}{l}39.9 \\
38.6\end{array}$ & $\begin{array}{l}29.2 \\
28.4\end{array}$ & $\begin{array}{l}22.0 \\
22.7\end{array}$ \\
\hline
\end{tabular}
Government Printing Office, Washington, D.C., Table 134.

U.S. Bureau of the Census, Census of Population: 1970, Detailed Characteristics, Final Report PC(1)-D Series, U.S. Government Printing Office, Washington, D.C., Table 193. 
males. The median income of black males, therefore, was equivalent to only about 60 percent of that of white males. Although there was a wide gap in income between black and white males as of 1970, over all, the income position of black males relative to white males improved between 1960 and 1970. For example, in 1960, the median income of black males 14 years old and over was only 53 percent of their white counterpart, as opposed to 60 percent in 1970. Also, as shown in Table 1, the index of dissimilarity between income distributions of black and white men 20 years old and over decreased from 32.9 percent in 1960 to 27.9 percent in 1970.

Sone comments should be made about the regional and interstate variations in the extent of race differentials in income. From a comparison between Table 1 and Table 2 we can observe that for the population 20 years old and over the extent of black-white income inequality observed in the Southern states was substantially greater than that in the Northern states. This was true for almost all age groups, in both 1960 and 1970. In both 1960 and 1970, the black-white differentials in the Southern states were consistently greater than those of the United States, while the Northern states generally had smaller differentials than the country as a whole.

Among the ten selected Southern states, Tennessee had the lowest index of dissimilarity in almost all age groups in both 1960 and 1970, whereas South Carolina and Mississippi had relatively larger indices of dissimilarity than the other Southern states. In addition, in both 1960 and 1970, the extent of race differentials in income in Tennessee was less than that of the country as a whole for most age groups. Among the seven selected Northern states, the differentials in New Jersey and New York were greater than those in the other Northern states, while Indiana had the lowest index of dissimilarity in both 1960 and 1970. It was interesting to note that, in 1970, Indiana had the lowest black population percentage among the seven Northern states, and Tennessee was ranked 9th among the ten Southern states.

We wondered if there was any significant association between interstate variations in the extent of black-white income differentials and educational and occupational inequality. The Spearman's rank-order correlation coefficients between indices of dissimilarity in black-white income distributions and indices of dissimilarity in educational and occupational distributions were computed for each age group. The results indicate that the interstate variations in black-white income inequality are closely related to the variations in educational and occupational inequality. For example, for the age group 25-34, the rank-order correlation coefficient between income and educational differentials was .721 for the ten Southern states, while it was .821 for the seven Northern states. The coefficients for other age groups were also significant. Furthermore, the correlation between income and occupational inequality was consistently significant for all age groups for both the Southern and Northern states. 
TABLE 2. Indices of Dissimilarity between Income Distributions of Black and White Males, by Age and State, for Selected Northern States, 1960 and 1970.

\begin{tabular}{lccrcccrrr}
\hline \hline & & Total, 20+ & $20-24$ & $25-34$ & $35-44$ & $45-54$ & $55-64$ & $65-74$ & $75+$ \\
\hline New York: & 1960 & 31.4 & 15.1 & 35.8 & 40.4 & 40.9 & 34.1 & 15.2 & 10.6 \\
& 1970 & 24.0 & 10.8 & 29.1 & 35.6 & 33.1 & 32.2 & 18.3 & 9.3 \\
New Jersey: & 1960 & 35.7 & 16.8 & 40.2 & 44.0 & 44.2 & 38.0 & 21.0 & 21.8 \\
& 1970 & 27.1 & 9.9 & 28.9 & 39.5 & 36.1 & 36.1 & 23.8 & 14.7 \\
Pennsylvania: & 1960 & 25.6 & 12.8 & 29.0 & 33.3 & 32.0 & 29.1 & 13.8 & 9.3 \\
& 1970 & 19.6 & 9.4 & 23.0 & 25.5 & 24.6 & 24.7 & 17.2 & 11.3 \\
Ohio: & 1960 & 28.1 & 21.3 & 34.0 & 35.4 & 35.8 & 32.4 & 15.4 & 10.9 \\
& 1970 & 20.2 & 8.2 & 22.0 & 30.6 & 27.8 & 25.3 & 22.4 & 18.9 \\
Indiana: & 1960 & 24.3 & 17.8 & 29.8 & 33.2 & 29.1 & 23.2 & 11.3 & 9.7 \\
& 1970 & 17.6 & 9.1 & 20.3 & 26.0 & 26.6 & 19.9 & 17.7 & 14.5 \\
Illinois: & 1960 & 28.4 & 15.0 & 34.0 & 37.9 & 35.7 & 30.9 & 16.5 & 14.2 \\
& 1970 & 24.5 & 11.3 & 25.2 & 36.6 & 35.6 & 30.1 & 23.0 & 16.7 \\
Michigan: & 1960 & 26.2 & 19.1 & 33.7 & 38.4 & 33.7 & 26.7 & 14.9 & 7.5 \\
& 1970 & 22.8 & 10.6 & 26.5 & 33.5 & 32.5 & 24.3 & 18.7 & 12.9 \\
\hline
\end{tabular}

Source: U.S. Bureau of the Census, Census of Population: 1960, Detailed Characteristics, Final Report PC(1)-D Series, U.S. Government Printing Office, Washington, D.C., Table 134.

U.S. Bureau of the Census, Census of Population: 1970, Detailed Characteristics, Final Report PC(1)-D Series, U.S. Government Printing Office, Washington, D.C., Table 193. 
The literature on black-white inequality suggests one possible line of inquiry on these observed patterns. More specifically, previous studies (Blalock, 1956; Blalock, 1957; Jiobu and Marshall, 1971) found a positive relationship between the relative size of black population and the degree of socioeconomic differentiation between blacks and whites. It was argued that "as the proportion of black population becomes larger, whites are increasingly threatened by black competitors for income, and discrimination arises to reduce this competition (Jiobu, 1972, pp. 605-606)." This competition hypothesis was also applied in the analysis of occupational variations in black-white earnings inequality (Hodge and Hodge, 1965; Hill, 1974; Shin, 1976).

Thus, we computed the rank-order correlation between the percent black population and black-white income inequality. The coefficient was .94 for the seventeen states all together, and for only the seven Northern states the coefficient was .79. However, the rank-order correlation coefficient for the ten Southern states was only .36. On the whole, our simple observation here seems to indicate that states with larger black population percentage tend to have relatively greater black-white income differentials, although the association is rather weak among the Southern states.

Table 3 presents intracohort and intercohort changes between 1960 and 1970 in indices of dissimilarity in black-white income distributions by state and age of cohort. For the population 25 years old and over as a whole, income inequality declined on both an intracohort and intercohort basis. A general comparison between the total intracohort (25+ in $1960 \rightarrow 35+$ in 1970) and intercohort $(25+$ in $1960 \rightarrow 25+$ in 1970) declines reveals an important pattern: the amount of intracohort declines is consistently greater than that of intercohort declines for all the states except New Jersey, Indiana, and Illinois. A detailed comparison within each cohort indicates that the amount of intracohort declines in racial income inequality for the 25-34 $\rightarrow$ 35-44 cohort is considerably less than the intercohort declines, while for the older cohorts $(35-44 \rightarrow$ $45-54,45-54 \rightarrow 55-64$, and 55-64 $\rightarrow$ 65-74) the amount of intracohort declines is consistently greater than that of intercohort declines for all the states considered. A greater intercohort decline in income inequality for younger age groups than for older age groups suggests that in 1970 young black men entering the labor market received income more equal to that of their white counterparts than in 1960 . However, the fact that the total intracohort decline is greater than the total intercohort decline implies that the contribution from the intercohort declines for younger age groups to the total changes of racial income inequality between 1960 and 1970 was not significant.

When we examine the regional variations in the total intracohort change, only three Southern states, Georgia, Florida, and South Carolina, experienced greater declines in racial income inequality than the United States as a whole. On the other hand, all the Northern states with the 
TABLE 3. Intracohort and Intercohort Changes in Indices of Dissimilarity between Black and White Income Distributions for Males, United States, Selected Southern and Northern States, between 1960 and 1970.

\begin{tabular}{|c|c|c|c|c|c|c|c|c|c|c|c|c|}
\hline & \multicolumn{12}{|c|}{ Age of Cohort in 1960 and 1970} \\
\hline & $\begin{array}{c}\text { Intracohort } \\
25+\text { in } 1960 \\
35+\text { in } 1970 \\
\end{array}$ & $\begin{array}{c}\text { Intercohort } \\
25+\text { in } 1960 \\
25+\text { in } 1970 \\
\end{array}$ & $\begin{array}{c}\text { Intracohort } \\
25-34 \text { in } 1960 \\
35-44 \text { in } 1970 \\
\end{array}$ & $\begin{array}{c}\text { Intercohort } \\
25-34 \text { in } 1960 \\
25-34 \text { in } 1970\end{array}$ & $\begin{array}{c}\text { Intracohort } \\
35-44 \text { in } 1960 \\
45-54 \text { in } 1970\end{array}$ & $\begin{array}{c}\text { Intercohort } \\
35-44 \text { in } 1960 \\
35-44 \text { in } 1970 \\
\end{array}$ & $\begin{array}{c}\text { Intracohort } \\
45-54 \text { in } 1960 \\
55-64 \text { in } 1970 \\
\end{array}$ & $\begin{array}{c}\text { Intercohort } \\
45-54 \text { in } 1960 \\
45-54 \text { in } 1970\end{array}$ & $\begin{array}{c}\text { Intracohort } \\
55-64 \text { in } 1960 \\
65-74 \text { in } 1970 \\
\end{array}$ & $\begin{array}{c}\text { Intercohort } \\
55-64 \text { in } 1960 \\
55-64 \text { in } 1970\end{array}$ & $\begin{array}{c}\text { Intracohort } \\
65+\text { in } 1960 \\
75+\text { in } 1970 \\
\end{array}$ & $\begin{array}{c}\text { Intercohort } \\
65+\text { in } 1960 \\
75+\text { in } 1970 \\
\end{array}$ \\
\hline U.S. & -4.2 & -3.5 & -2.1 & -5.9 & -3.4 & -3.8 & -5.5 & -2.1 & -7.2 & -1.3 & -1.9 & -.5 \\
\hline Va. & -0.8 & -0.9 & +4.8 & -3.5 & -2.5 & -1.0 & -5.7 & +2.5 & -7.6 & +1.1 & -1.3 & +1.1 \\
\hline N.C. & -5.5 & -4.6 & -4.2 & -10.2 & -7.2 & -4.6 & -6.8 & -0.1 & -14.0 & +0.3 & -4.2 & -3.0 \\
\hline S.C. & -6.2 & +2.2 & -3.8 & -10.0 & -6.8 & -5.1 & -10.4 & -1.5 & -16.6 & -0.3 & -3.4 & -6.5 \\
\hline Ga. & -6.6 & -5.3 & -3.7 & -9.0 & -4.3 & -3.5 & -6.4 & +1.1 & -14.9 & +1.2 & -4.5 & -12.0 \\
\hline Fla. & -6.4 & -6.2 & +0.2 & -12.0 & -7.1 & -4.4 & -9.5 & -0.5 & -0.6 & +1.0 & +5.8 & +2.8 \\
\hline Tenn. & -2.5 & -2.0 & -2.4 & -9.5 & -3.9 & -2.4 & -5.2 & +3.4 & -11.1 & -1.6 & -2.5 & -1.5 \\
\hline Ala. & -2.6 & -0.5 & -2.9 & -4.8 & -6.6 & -1.2 & -4.1 & +3.2 & -6.5 & +3.2 & -6.0 & -3.0 \\
\hline Miss. & -3.0 & -0.7 & -2.7 & -6.5 & -7.3 & -3.8 & -6.0 & +3.8 & -11.2 & +0.9 & -3.8 & -1.2 \\
\hline Ark. & -3.9 & -2.4 & -8.7 & -9.3 & -9.0 & -7.9 & -7.8 & +1.3 & -6.2 & -0.1 & -3.4 & +.8 \\
\hline La. & -4.2 & -2.7 & -2.7 & -6.2 & -7.2 & -3.5 & -6.9 & +0.8 & -11.6 & -1.3 & -2.4 & +.9 \\
\hline N.Y. & -6.6 & -6.5 & -0.2 & -6.7 & -7.3 & -4.8 & -8.7 & -7.8 & -15.8 & -1.9 & -3.4 & +1.5 \\
\hline N.J. & -7.4 & -7.6 & -7.0 & -11.3 & -7.9 & -4.5 & -8.1 & -8.1 & -14.2 & -1.9 & +8.1 & +1.1 \\
\hline Pa. & -6.6 & -6.1 & -3.4 & -6.0 & -8.6 & -7.8 & -7.3 & -7.4 & -12.0 & -4.4 & +0.2 & +2.8 \\
\hline Ohio & -6.4 & -7.0 & -3.4 & -12.0 & -7.6 & -4.8 & -10.0 & -7.1 & -10.0 & -7.1 & +6.4 & +6.8 \\
\hline Ind. & -5.4 & -6.0 & -3.8 & -9.5 & -6.6 & -7.2 & -9.2 & -2.5 & -5.5 & -3.3 & +5.1 & +5.7 \\
\hline Ill. & -1.8 & -2.5 & -2.6 & -8.8 & -2.3 & -1.3 & -5.6 & -0.1 & -7.9 & -0.8 & +2.1 & +4.2 \\
\hline Mich. & -3.6 & -3.1 & -0.2 & -7.2 & -6.0 & -4.9 & -9.4 & -1.2 & -8.0 & -2.4 & +0.8 & +3.4 \\
\hline
\end{tabular}

Source: Tables 1 and 2 . 
exception of Illinois and Michigan had greater reductions than the country as a whole. Therefore, not only is the extent of income inequality greater in the Southern states than in the Northern states, but the amount of decline in racial inequality is also less for the Southern states. Within the South, the interstate variations in the amount of decline in black-white income differentials between 1960 and 1970 seem to be related to the variations in the levels of income differential in 1960. The amount of decline tends to be greater for those which had relatively higher index of dissimilarity in 1960. The rank-order correlation between the two variables for the South was .67. However, the correlation for the North and the seventeen states as a whole was rather weak.

A detailed examination of changes in income inequality within each cohort indicates that the racial income inequality declined between 1960 and 1970 in three cohorts, 35-44 $\rightarrow$ 45-54, 45-54 $\rightarrow$ 55-64, and 55-64 $\rightarrow$ 65-74, for all the 17 states without any exception. For the cohort of $25-34 \rightarrow 35-44$, all but two states (Virginia and Florida) showed declines, while for the $65+\rightarrow 75+$ cohort 10 of the 17 states had declines in income inequality. For the $65+\rightarrow 75+$ cohort, all the Northern states except New York have some increase in the income inequality. The reasons for this phenomenon are not clear. However, having an open-ended age cohort might have been a problem for an observation of intracohort changes during a specific period of time.

A very consistent pattern of variations in the extent of intracohort declines by age of cohort can be observed from Table 3: disregarding the cohort of $65+\rightarrow 75+$, the older the age of cohort, the greater the amount of decrease in race differentials in income. This pattern was observed from the United States as a whole and most of the states considered. We wondered if the observed age patterns of intracohort changes in income inequality are related to the changing patterns of black-white differentials in the characteristics of the labor force. First, we compared the arnount of intracohort changes in the black-white differential in the percentage of population who worked 50-52 weeks by the age of cohort. As shown in Table 4, the amount of intracohort decline between 1960 and 1970 in the black-white difference in the percentage worked 50-52 weeks tends to increase as age of cohort increases. The extent of regularity in the labor market activity is obviously one of the important determinants of income. The fact that a greater convergence between blacks and whites in the regularity of labor market activity has occurred among the older cohorts than among the younger cohorts could have contributed to the observed age pattern of intracohort changes in the black-white income differentials.

Secondly, since the black-white differential in the labor force participation rates may be an important factor in the black-white income differentials, we have examined the census data on the intracohort changes between 1960 and 1970 in the black-white differential of the labor force participation rates (U.S. Bureau of the Census, 1963: Table 194; U.S. 
TABLE 4. Intracohort Change of the Black-White Differential in the Percentage Worked 50-52 Weeks by Age of Cohort, for Males, United States, 1960-1970

\begin{tabular}{|c|c|c|c|c|c|c|c|c|}
\hline \multirow[b]{2}{*}{ Age in 1960} & \multicolumn{3}{|c|}{ Percent Worked 50-52 Weeks in 1959} & \multirow[b]{2}{*}{ Age in 1970} & \multicolumn{3}{|c|}{ Percent Worked 50-52 Weeks in $1969^{\circ}$} & \multirow{2}{*}{$\begin{array}{c}\text { Intracohort Change } \\
\text { in Black-White } \\
\text { Difference in the Percentage } \\
\text { Worked 50-52 Weeks } \\
(7)=(6)-(3)\end{array}$} \\
\hline & $\begin{array}{l}\text { White } \\
\text { (1) }\end{array}$ & $\begin{array}{c}\text { Nonwhite } \\
\text { (2) }\end{array}$ & $\begin{array}{l}\text { White-Nonwhite } \\
\text { Difference in } 1960 \\
(3)=(1)-(2)\end{array}$ & & $\begin{array}{l}\text { White } \\
\text { (4) }\end{array}$ & $\begin{array}{c}\text { Black } \\
(5)\end{array}$ & $\begin{array}{c}\text { White-Black } \\
\text { Difference in } 1970 \\
(6)=(4)-(5)\end{array}$ & \\
\hline $25-34$ & 71.9 & 52.3 & 19.6 & $35-44$ & 80.1 & 62.2 & 17.9 & -1.7 \\
\hline $35-44$ & 75.3 & 54.8 & 20.5 & $45-54$ & 77.1 & 59.4 & 17.7 & -2.8 \\
\hline $45-54$ & 74.7 & 51.9 & 22.8 & $55-64$ & 64.9 & 49.5 & 15.4 & -7.4 \\
\hline $55-64$ & 60.9 & 43.7 & 17.2 & $65-74$ & 21.4 & 16.8 & 4.6 & -12.6 \\
\hline
\end{tabular}

Source: U.S. Bureau of the Census, U.S. Census of Population: 1960. Detailed Characteristics, United States Summary, Final Report PC(1)-1D, Table 199, U.S. Government Printing Office, Washington, D.C., 1963.

U.S. Bureau of the Census, U.S. Census of Population: 1970. Detailed Characteristics Final Report PC(1)-D1, United States Summary, Table 218, U.S. Government Printing Office, Washington, D.C., 1973. 
Bureau of the Census, 1973: Table 215). Our examination of the data revealed that there is no clear association between the amount of intracohort changes in the black-white differential in the labor force participation and the age of cohort, and thus the intracohort changes in the labor force participation rates are not consistent with the age patterns of intracohort change in the black-white income differentials.

Thirdly, the intracohort changes between 1960 and 1970 in the blackwhite differentials in occupational distributions of employed persons are compared among the different cohorts. Table 5 shows that the indices of dissimilarity between black and white male occupational distributions for both the 25-34 $\rightarrow$ 35-44 and 35-44 $\rightarrow$ 45-54 cohorts did not change significantly during the $1960-1970$ period. Moreover, the $45-54 \rightarrow$ 55-64 cohort experienced an increase in occupational differentiation. Therefore, the patterns of intracohort changes in the occupational distribution do not seem to explain the patterns of intracohort changes in the income differential.

One may argue that although the index of dissimilarity in occupational distributions based on the broad occupational categories did not decrease within each cohort, the detailed occupational distribution still could have changed in a manner favorable for a greater intracohort decline in the income differential for the older cohorts than for younger cohorts. Thus, we checked the census data (U.S. Bureau of the Census, 1963, Table 204; U.S. Bureau of the Census, 1973, Table 226) on the intracohort changes between 1960 and 1970 in occupational distribution of blacks. Again, there was no clear evidence that the intracohort changes in occupational distribution of black males would have produced a greater decrease in the income differential for the older cohorts than for the younger cohorts.

Fourthly, we checked whether the intracohort change in black-white inequality in educational distributions shows an age pattern similar to the observed pattern of income differentials. Table 6 indicates that the racial inequality in educational distributions for the cohort 25-34 $\rightarrow$ 3544 increased between 1960 and 1970 . However, no significant similarity between the age patterns of intracohort changes in income and educational inequality can be observed. Therefore, among several aspects of the labor force characteristics considered here only one variable, that is the percentage worked 50-52 weeks, showed a pattern corresponding to that of intracohort changes in the black-white income differentials during the 1960-70 decade.

Still another possible explanation of the observed age patterns of intracohort changes in black-white inequality can be suggested. In their recent study, Long and Heltman (1975: 1394) found that "Southern-born blacks who lived in the North for five years or more had higher incomes and were less likely to be at the lowest income level (below $\$ 3,000$ ) than were northern-born blacks of the same age." On the other hand, they observed that "the median income of white men who moved from the 
TABLE 5. Intracohort Change in the Indices of Dissimilarity between Black and White Male Occupational Distributions, United States, between 1960 and 1970

\begin{tabular}{|c|c|c|c|c|}
\hline Age of Cohort in 1960 & $\begin{array}{c}\text { Index of } \\
\text { Dissimilarity in } 1960\end{array}$ & Age of Cohort in 1970 & $\begin{array}{c}\text { Index of } \\
\text { Dissimilarity in } 1970\end{array}$ & $\begin{array}{c}\text { Intracohort } \\
\text { Change in } \\
\text { the Index of } \\
\text { Dissimilarity between } \\
1960 \text { and } 1970\end{array}$ \\
\hline $25-34$ & 34.0 & $35-44$ & 34.2 & +0.2 \\
\hline $35-44$ & 37.2 & $45-54$ & 36.9 & -0.3 \\
\hline $45-54$ & 38.8 & $55-64$ & 46.1 & +7.3 \\
\hline
\end{tabular}

Source: U.S. Bureau of the Census, U.S. Census of Population: 1960. Detailed Characteristics. United States Summary, Final Report PC(1)-1D, Table 204, U.S. Government Printing Office, Washington, D.C., 1963.

U.S. Bureau of the Census, U.S. Census of Population: 1970. Detailed Characteristics. Final Report PC(1)-D1, United States Summary, Table 226, U.S. Government Printing Office, Washington, D.C., 1973. 
TABLE 6. Intracohort Change in the Indices of Dissimilarity between Black and White Male Educational Distributions, United States, between 1960 and 1970.

\begin{tabular}{lcccc}
\hline \hline $\begin{array}{c}\text { Age of } \\
\text { Cohort in 1960 }\end{array}$ & $\begin{array}{c}\text { Index of } \\
\text { Dissimilarity in 1960 }\end{array}$ & $\begin{array}{c}\text { Age of } \\
\text { Cohort in 1970 }\end{array}$ & $\begin{array}{c}\text { Index of } \\
\text { Dissimilarity in 1970 }\end{array}$ & $\begin{array}{c}\text { Intracohort Change in } \\
\text { the Index of Dissimilarity } \\
\text { between 1960 and 1970 }\end{array}$ \\
\hline Total, 25+ & 29.5 & Total, 35+ & 29.4 & -0.1 \\
$25-34$ & 19.9 & $35-44$ & 27.4 & +7.5 \\
$35-44$ & 29.8 & $45-54$ & 29.0 & -0.8 \\
$45-54$ & 38.4 & $55-64$ & 37.6 & -0.8 \\
$55-64$ & 40.5 & $65-74$ & 40.8 & -0.3 \\
$65+$ & 38.1 & $75+$ & 35.9 & -2.2 \\
\hline
\end{tabular}

Source: U.S. Bureau of the Census, U.S. Census of Population: 1960. Detailed Characteristics, United States Summary. Final Report PC (1)-1D, Table 173, U.S. Government Printing Office, Washington, D.C., 1963.

U.S. Bureau of the Census, U.S. Census of Population: 1970. Detailed Characteristics, Final Report PC (1)-D1, United States Summary, Table 199, U.S. Government Printing Office, Washington, D.C., 1973. 
South is lower than that among. white men of similar age in the North or West who are not interregional migrants (Long and Heltman, 1975: 1394)." These findings seem to suggest that the redistribution of black population through continued migration from the South to the North and West could have contributed to reducing the black-white income inequality.

However, if we were to argue that the income selectivity of outmigration of blacks from the South caused the observed age pattern of the intracohort changes in income inequality, we would have to prove that the selectivity of blacks with high income was greater for younger age groups than for older age groups in the outmigration from the South. Interestingly, the age pattern of income selectivity of black migrants from the South to the North during the 1965-70 period is in the hypothesized direction. As shown in Table 7, within each educational level there is an inverse relationship between age of migrants and extent of income selectivity: the younger the age of migrants, the greater the income selectivity. Thus, it is possible that the observed smaller decline in income inequality for younger cohorts in the South is influenced by greater income selectivity in the outmigration of blacks from the South.

It is interesting to note that the age patterns of intercohort changes in income inequality are somewhat contradictory to the age patterns of intracohort changes. As shown in Table 3, in the intercohort changes younger age groups experienced greater declines in income inequality than older age groups. In fact, many of the older age groups for both the South and the North show some increases in racial income inequality. As in the case of our examination of the age patterns of intracohort changes, we checked whether the observed age patterns of intercohort changes in income inequality are related to the intercohort changes in the percentage worked 50-52 weeks, labor force participation rates, and occupational distributions. None of these variables showed any relationship with the age patterns of intercohort changes in racial income inequality.

\section{SUMMARY AND DISCUSSION}

Using the data in the published census reports, this paper analyzed the cohort changes in black-white male income differentials in the South during the 1960-1970 decade. From the data we observed that black-white income inequality in the Southern states decreased between 1960 and 1970. However, the extent of decline in the Southern states was less than that of the Northern states and the country as a whole. Also, there were significant interstate variations within the South in the extent of decline of the black-white income inequality. In general, the black-white income gap has been narrowed within each cohort. The amount of intracohort declines in income inequality is consistently greater than intercohort declines in all but the youngest cohort considered, 25-34 $\rightarrow$ 35-44. Furthermore, there was an inverse relationship between the age of cohort 
TABLE 7. Ratio of Median Income in 1969 of Black Males born in South who Migrated to North between 1965 and 1970 to Median Income in 1969 of Black Males born in South who did not Migrate to Other Regions between 1965 and 1970, by Age and Educational Level.

\begin{tabular}{|c|c|c|c|}
\hline $\begin{array}{l}\text { Educational Level } \\
\text { and Age }\end{array}$ & $\begin{array}{l}\text { Black Males Born in South } \\
\text { and did not Migrate to } \\
\text { Other Regions Retween } \\
1965 \text { and } 1970 \\
\text { (1) }\end{array}$ & $\begin{array}{c}\text { Black Males Born in South } \\
\text { who Migrated to North } \\
\text { Between } 1965 \text { and } 1970 \\
\text { (2) }\end{array}$ & $\begin{array}{l}\text { Ratio of } \\
\text { (2) to (1) }\end{array}$ \\
\hline \multicolumn{4}{|l|}{ Elementary: $0-8$} \\
\hline $25-34$ & $\$ 3,351$ & $\$ 5,164$ & 1.54 \\
\hline $35-44$ & 3,928 & 4,978 & 1.27 \\
\hline $45-64$ & 3,190 & 3,762 & 1.18 \\
\hline \multicolumn{4}{|l|}{ High School: 1-3 } \\
\hline $25-34$ & 4,454 & 5,524 & 1.24 \\
\hline $35-44$ & 4,834 & 5,551 & 1.15 \\
\hline $45-64$ & 4,569 & 4,949 & 1.08 \\
\hline \multicolumn{4}{|l|}{ High School: 4} \\
\hline $25-34$ & 5,189 & 6,387 & 1.23 \\
\hline $35-44$ & 5,518 & 5,786 & 1.05 \\
\hline $45-64$ & 5,111 & 5,698 & 1.12 \\
\hline \multicolumn{4}{|l|}{ College: $1-3$} \\
\hline $25-34$ & 5,780 & 7,078 & 1.23 \\
\hline $35-44$ & 6,350 & 7,418 & 1.17 \\
\hline $45-64$ & 5,790 & 5,305 & .92 \\
\hline \multicolumn{4}{|l|}{ College: $4+$} \\
\hline $25-34$ & 7,310 & 8,714 & 1.19 \\
\hline $35-44$ & 9,260 & 10,519 & 1.14 \\
\hline $45-64$ & 10,344 & 9,999 & .97 \\
\hline
\end{tabular}

Source: U.S. Bureau of the Census, Census of Population: 1970. Subject Reports. Final Report PC(2)-2B. Mobility for States and the Nation. U.S. Government Printing Office, Washington, D.C., 1973. 
and the extent of intracohort declines in the income differentials. On the other hand, in the intercohort changes younger age groups showed greater declines in income inequality than older age groups. We attempted to link the observed age patterns of intracohort and intercohort changes in income inequality to the cohort changes in the labor force characteristics. However, none of the characteristics considered provide clear explanation for the age patterns of income inequality. As noted earlier, we are dealing with changes in the race differentials in income of the "open cohorts," rather than "closed cohorts." Thus, mortality and migration factors, particularly migration differentials and selectivities, have influenced the outcome of the age patterns of cohort changes in black-white income inequality.

McKinney and Bourque (1971:399) asserted that "the South has been changing more rapidly than the rest of the nation and moreover is becoming increasingly indistinguishable from the rest of American society" in terms of "primary dimensions of living" such as education, occupational distribution, urbanization and the like. The observed regional variations in racial differentiation of income which persisted during the 1960s suggest the need for further improvement of income status of blacks in the South. Nevertheless, the recent findings that southern-born black migrants in the North earn higher incomes than northern-born blacks (Long and Heltman, 1975) lead to some optimism about the possible future reductions of the income inequality between the two race groups.

\section{REFERENCES}

Blalock, Hubert. "Economic Discrimination and Negro Increase." American Sociological Review 21: 584-588, 1956.

Blalock, Hubert. "Percent Nonwhite and Discrimination in the South." American Sociological Review 22: 677-682, 1957.

Bogue, Donald J. Principles of Demography. New York: John Wiley and Sons, 1969.

Cook, Thomas J. "Benign Neglect: Minimum Feasible Understanding." Social Problems 18 (Fall): 145-152, 1970.

Cutright, Phillips. "Region, Migration and the Earnings of White and Black Men." Social Forces 53: 297-305, 1974.

Duncan, Otis Dudley and Beverly Duncan. "A Methodological Analysis of Segregation Indexes." American Sociological Review 20: 210-217, 1955.

Farley, Reynolds and Albert Hermalin. "The 1960's: A Decade of Progress for Blacks?" Demography 9 (August): 353-370, 1972.

Fein, Rashi. "An Economic and Social Profile of the Negro American." Daedalus 94 (Fall): 815-846, 1965.

Fox, William S. and John R. Faine. "Trends in White-Nonwhite Income Equality." Sociology and Social Research 57 (April): 288299, 1973
Hamilton, C. Horace. "The Negro Leaves the South." Demography 1: 273-295, 1964.

Hill, Richard C. "Unionization and Racial Income Inequality in the Metropolis." American Sociological Review 39 (August): 507522,1974

Hodge, Robert W. and Patricia Hodge. "Occupational Assimilation as a Competitive Process." American Journal of Sociology 71 (November): 249-264, 1965.

Jiobu, Robert M. "Urban Determinants of Racial Differentiation in Infant Mortality." Demography 9 (November): 603-616, 1972.

Jiobu, Robert M. and Harvey H. Marshall. "Urban Structure and the Differentiation between Blacks and Whites." American Sociological Review 36 (August): 638-649, 1971.

Long, Larry H. and Lynne R. Heltman. "Income Differences between Blacks and Whites Controlling for Education and Region of Birth." American Journal of Sociology 80 (May): 1391-1409, 1975.

McKinney, John C. and Linda B. Bourque. "The Changing South: National Incorporation of a Region." American Sociological Review 36 (June): 399-412, 1971.

Moynihan, Daniel P. "The Schism in Black America." The Public Interest 27 (Spring): 3-24, 1972. 
Price, Daniel O. "Effects of Outmigration on Educational Level of Negro Males in Southern United States." U.N. World Population Conference, Belgrade, 1965, A6/V/E/440. Changing Characteristics of the Negro Population (A 1960 Census Monograph). Washington, D.C.: U.S. Government Printing Office, 1969.

Shin, Eui Hang. "Earnings Inequality between Black and White Males by Education, Occupation, and Region." Sociology and Social Research 60 (January): 162-172, 1976.

Shryock, Henry S. and Charles B. Nam. "Educational Selectivity of Interregional Migration." Social Forces 43: 299-310, 1965.

Siegel, Jacob S. "Estimates of Coverage of the Population by Sex, Race, and Age in the 1970 Census." Demography 11 (February): 1-23, 1974.

Siegel, Paul M. "On the Cost of Being a Negro." Sociological Inquiry 35 (Winter): 4157, 1965.

Suval, Elizabeth M. and C. Horace Hamilton. "Some New Evidence on Educational Selectivity in Migration to and from the South." Social Forces 44: 536-547, 1965.
Taeuber, Karl E. and Alma F. Taeuber. "The Changing Character of Negro Migration." American Journal of Sociology 70: 429-441, 1965a.

Negroes in Cities. Chicago: Aldine Publishing Co., 1965b.

U.S. Bureau of the Census. U.S. Census of Population: 1960. Detailed Characteristics. United States Șummary. Final Report PC (1) -1D, 1963.

"Differences between Incomes of White and Negro Families by Work Experience of Wife and Region: 1970, 1969, and 1959," Current Population Reports, Series P-23, No. 39, 1971.

U.S. Census of Population: 1970. General Population Characteristics. Final Report PC (1)-B1. United States Summary, 1972.

U.S. Census of Population: 1970. Vol. 1, Characteristics of the Population. Part 1, United States Summary, 1973.

"The Social and Economic Status of the Black Population in the United States, 1970." Current Population Reports, Special Studies, Series P-23, No. 38, 1974. 